This is a final peer-reviewed accepted manuscript. The final published version is available online at: https://doi.org/10.1016/j.ifset.2017.02.002

(c) 2017 Elsevier. This manuscript version is made available under the Creative Commons Attribution-NonCommercial-NoDerivs (CC BY-NC-ND) 4.0 International License (http://creativecommons.org/licenses/by-nc-nd/4.0/)

\title{
Influence of ultrasound-assisted osmotic dehydration on the main quality parameters of kiwifruit
}

\author{
M. Nowacka a ${ }^{\mathrm{a}}$ U. Tylewicz ${ }^{\mathrm{b}, *}$, S. Romani ${ }^{\mathrm{b}, \mathrm{c}}$, M. Dalla Rosa ${ }^{\mathrm{b}, \mathrm{c}}$, D. Witrowa-Rajchert ${ }^{\mathrm{a}}$ \\ ${ }^{a}$ Faculty of Food Sciences, Department of Food Engineering and Process Management, Warsaw University of Life Sciences (WULS-SGGW), Warsaw, Poland ${ }^{\mathrm{b}}$ Department of Agricultural \\ and Food Sciences, Alma Mater Studiorum Università di Bologna, Campus of Food Science, Cesena, Italy ${ }^{\mathrm{c}}$ Interdepartmental Centre for Agri-Food Industrial Research, Alma Mater \\ Studiorum Università di Bologna, Campus of Food Science, Cesena, Italy
}

Keywords:

Kiwifruit

Ultrasound

Texture

Color

Chlorophyll

Water activity
(OD), on texture, color, chlorophyll content, water activity and freezable water content of kiwifruit. Kiwifruit slices were subjected to ultrasonic waves in the bath at a frequency of $35 \mathrm{kHz}$ for 10,20 and $30 \mathrm{~min}$. Afterwards, the OD was carried out by immersion of samples in $61.5 \%$ sucrose solution for pre-established contact period of $0,10,20,30,60$ and 120 min. From the obtained results it was possible to observe that the effect of US, on overall kiwifruit quality parameters, was not proportionally related to the treatment times. US pretreatment alone positively affected the chlorophyll content, when applied for 20 min, while texture parameter was negatively influenced by all the tested US condi-tions. When combined with OD, US was able to maintain and sometimes improve the kiwifruit characteristics. Industrial relevance: Ultrasound is a pretreatment widely used to improve the mass transfer in osmotic dehydra-tion process. The results of this research have demonstrated that the US treatment applied on kiwifruit slices did not promote the deterioration of the product quality. In fact, it was able to maintain or, in certain treatment times, even to improve some quality parameters (e.g. chlorophyll content) of kiwifruit subjected to osmotic dehydra-tion process. Therefore, the ultrasound treatment shows high potentials to be applied at industrial level to reduce the time of osmotic dehydration and to obtain novel products with high quality.

\section{Introduction}

Power or high intensity ultrasound is a mechanical wave of frequencies above the human hearing, staying in the range between $20 \mathrm{kHz}$ and 100 kHz (McClements, 1995; Mason, 1998; Feng \& Yang, 2006). It is based on a rapid series of compressions followed by expansions of the tissue (sponge effect), promoting the alteration of structural and physico-chemical characteristics of food products (McClements, 1995; Fernandes, Gallão, \& Rodrigues, 2009). Power ultrasound finds many applications in food processing operations such as drying (Cárcel, Garcia Perez, Riera, \& Mulet, 2007; Fernandes \& Rodrigues, 2007; Fernandes, Gallão, \& Rodrigues, 2008; Fernandes et al., 2009; Schössler, Thomas, \& Knorr, 2012; Nowacka \& Wedzik, 2016), osmotic dehydration (Simal, Benedito, Sanchez, \& Rossello, 1998; Nowacka, Tylewicz, Laghi, Dalla Rosa, \& Witrowa-Rajchert, 2014), freezing by induction of nucleation (Comandini et al., 2013), inactivation of microbes and enzymes (Benedito, Ortuño, Castillo-Zamudio, \& Mulet, 2015) etc.

\footnotetext{
* Corresponding author at: Department of Agricultural and Food Sciences, Alma Mater Studiorum, Università di Bologna, Campus of Food Science, Piazza Goidanich, 60, 47521 Cesena, Italy.

E-mail address: urszula.tylewicz@unibo.it (U. Tylewicz).
}

During osmotic dehydration (OD), which is the partial dewateringimpregnation process carried out by immersion of cellular tissue in lower water activity $\left(\mathrm{a}_{\mathrm{w}}\right)$ solutions, several chemico-physical changes in treated samples may occur. OD promotes the $\mathrm{a}_{\mathrm{w}}$ reduction (Gianotti, Sacchetti, Guerzoni, \& Dalla Rosa, 2001; Silva, Fernandes, \& Mauro, 2014) and the freezable water content decrease (Cornillon, 2000; Tylewicz et al., 2011; Cheng, Zhang, Adhikari, \& Islam, 2014), allowing to obtain safe products with low/intermediate water content. After OD operation the product is often subjected to drying process in order to obtain high stability. The OD process causes a partial removal of water from food product, that can influence on shortening the drying time (Garcia, Mauro, \& Kimura, 2007; Rudy et al., 2013). However the drying time could also be extended due to internal resistance of OD treated foodstuff to mass transfer caused by the solute uptake, which occurs in the osmotic process. Moreover, drying process led also to a greater loss of bioactive compounds due to the high temperature used in the process (El-Aouar, Azoubel, \& Xidieh Murr, 2003).

The OD treatment can cause some structural modifications of the processed plant tissue (volume reduction, plasmolysis, loss of cell wall integrity etc.), which consequently may affect its mechanical properties such as texture (Alzamora, Castro, Vidales, Nieto, \& Salvatori, 2000, chap. 9; Chiralt et al., 2001; Panarese, Tylewicz, Santagapita, Rocculi, \& 
Dalla Rosa, 2012; Panarese, Laghi, Pisi, Tylewicz, Dalla Rosa, \& Rocculi, 2012; Kek, Chin, \& Yusof, 2013). Since during OD process there is a loss of pigments from the product into the osmotic solution, a modification of the fruit and vegetables color may also occur (Osorio et al., 2007; Tylewicz, Rząca, Rocculi, Romani, \& Dalla Rosa, 2010). However, when compared to thermal treated products, better green color maintenance was observed in kiwifruit samples, inasmuch the time to converse chlorophyll into pheophytins was reduced by OD application (Dalla Rosa \& Bressa, 1995). In general, the color of plant tissue is a very important food quality feature, which plays a significant role for consumers, influencing their choices. It can be affected by chemical reactions, physical changes and nutritional components decrease (e.g. $\beta$-carotene) during technological processes (Perera, 2005; Kutyła-Olesiuk, Nowacka, Wesoły, \& Ciosek, 2013; Aadil, Zeng, Han, \& Sun, 2013; Pathare, Opara, \& Al-Julanda Al-Said, 2013; Nuncio-Jáuregui, Calín-Sánchez, Carbonell-Barrachina, \& Hernández, 2014).

Power ultrasound applied before osmotic dehydration process may have an impact on the structure of fruit tissue (Fernandes et al., 2008; Schössler et al., 2012; Nowacka et al., 2014). The "sponge effect" promoted by application of ultrasound results in microscopic channels creation in the fruit tissue. Moreover, this process is often accompanied by breakdown of cell wall, loss of cell adhesion, elongation and disruption of continuous cells etc. (Tarleton \& Wakeman, 1998; Fernandes et al., 2008; Nowacka et al., 2014).

It is well known that ultrasound application can enhance the mass transfer during osmotic dehydration of different fruit tissues (Simal et al., 1998; Luchese, Gurak, \& Ferreira Marczak, 2015). In our previous work, we demonstrated that the use of ultrasound treatment for 20 and 30 min prior osmotic dehydration had a positive effect on improving water loss and solid gain in kiwifruit tissue (Nowacka et al., 2014). However, to the best of our knowledge, the impact of the combination of these treatments on kiwifruits quality parameters has not been yet investigated. Therefore, the aim of this study was to analyze the selected chemical and physical properties of differently treated kiwifruit samples. In particular, the water activity, freezable water content, texture, color and chlorophyll content of ultrasound treated kiwifruit were investigated. Moreover, the effect of combined treatments (US pretreatment and OD process) on above mentioned physico-chemical kiwifruit characteristics was also investigated.

\section{Materials and methods}

\subsection{Raw material}

Kiwifruits (Actinidia deliciosa var. deliciosa cv Hayward) with homogeneous size and soluble solid content of $12 \pm 1^{\circ}$ Brix were bought on the local market and stored for 3 weeks in controlled atmospheric condition $\left(4 \pm 1{ }^{\circ} \mathrm{C}, 90-95 \% \mathrm{RH}\right)$ until processing. Kiwifruits were hand peeled, cut into $10 \pm 1 \mathrm{~mm}$ thick slices and subjected to ultrasound and osmotic dehydration treatments.

\subsection{Ultrasound (US) pretreatment}

The kiwifruit slices were immersed in distilled water and placed in an ultrasonic bath (TransSonic TP 690-A, Elma, Germany, internal dimensions: $135 \times 100 \times 520 \mathrm{~mm}$ ) working at a frequency of $35 \mathrm{kHz}$ for 10, 20 and $30 \mathrm{~min}$. Acoustic intensity was expressed as ultrasonic power delivered to the specified mass of ultrasonic treated sample $(\mathrm{W} / \mathrm{g})$ The intensity of ultrasound was equal to $8.4 \cdot 10^{-2} ; 9.7 \cdot 10^{-2}$; $10.2 \cdot 10^{-2} \mathrm{~W} / \mathrm{g}$ for time of 10,20 and $30 \mathrm{~min}$, respectively. The power of ultrasound was calculated using the following equation (Raso, Manas, Pagan, \& Sala, 1999):

$$
\mathrm{P}=\mathrm{MC}_{\mathrm{p}} \frac{\mathrm{dT}}{\mathrm{dt}}
$$

where: $\mathrm{P}$ is the ultrasonic power, $\mathrm{M}$ is the mass of the solution, $\mathrm{dT} / \mathrm{dt}$ is the increase of temperature, $\mathrm{Cp}$ is the heat capacity of the solution.

The slices were covered with the metal net to avoid flow out of the samples. The treatment was carried out at room temperature $\left(25^{\circ} \mathrm{C}\right)$. The ratio of raw material to water was set to $1: 4(\mathrm{w} / \mathrm{w})$, as suggested by Fernandes et al. $(2008,2009)$. After US treatment the plant materials were blotted with filter paper and subjected to osmotic dehydration. Before and after US treatment the samples mass, dry matter content and water temperature were measured. The temperature increase during the experiments was equal to 3,5 and $10^{\circ} \mathrm{C}$ after 10,20 and $30 \mathrm{~min}$ of US treatment, respectively; this phenomenon was also observed by other authors (Jambrak, Mason, Paniwnyk, \& Lelas, 2007; Nowacka, Wiktor, Sledz, Jurek, \& Witrowa-Rajchert, 2012; Kek et al., 2013; Nowacka \& Wedzik, 2016).

Control samples were prepared by dipping kiwifruit slices (DIP) in distilled water at the same temperature/time conditions of US treated samples, without the application of ultrasound.

\subsection{Osmotic dehydration (OD) treatment}

Kiwifruit slices were placed in mesh baskets and immersed in $61.5 \%$ $(\mathrm{w} / \mathrm{w})$ sucrose solution. The osmotic solution: kiwifruit ratio was of $4: 1$ $(\mathrm{w} / \mathrm{w})$, to avoid changes in the solution concentration during the treatment. The final OD time was assessed at $120 \mathrm{~min}$, on the basis of previous works carried out on kiwifruit (Nowacka et al., 2014). The chosen properties were analyzed on kiwifruit samples after established OD time intervals: $0,10,20,30,60$ and $120 \mathrm{~min}$. The process temperature was controlled using thermocouple in the water bath set at $25^{\circ} \mathrm{C}$. The baskets were continuously stirred with a propeller with a speed of $88 \mathrm{rpm}$. After removal from the solution, the dehydrated kiwifruit samples were rinsed with $200 \mathrm{ml}$ of distilled water for $10 \mathrm{~s}$ and blotted with absorbent paper to remove excess of solution. The experiments were conducted in duplicate for each osmotic dehydration process.

All obtained samples are summarised with related abbreviations in Table 1.

\section{Qualitative determinations}

\subsection{Water activity}

Water activity $\left(\mathrm{a}_{\mathrm{w}}\right)$ was measured in the water activity meter AquaLab Series 3TE (Decagon Devices, Inc., USA) at room temperature. The measurements were conducted in triplicate.

\subsection{Freezable water content by differential scanning calorimetry (DSC)}

Control and treated samples of about 20-30 mg were weighted into a $50 \mu \mathrm{l}$ hermetic stainless steel pans and analyzed by using differential scanning calorimeter - Pyris 6 DSC (Perkin-Elmer Corporation, Wellesley, USA). An empty pan was used as a reference. The DSC was equipped with a low-temperature cooling unit Intracooler II (Perkin-Elmer Corporation, Wellesley, USA). Temperature and melting enthalpy calibrations were performed with ion exchanged distilled water $\left(\mathrm{mp} 0.0^{\circ} \mathrm{C}\right)$,

Table 1

Abbreviations of analyzed samples.

\begin{tabular}{lll}
\hline Treatment & Abbreviations & \\
\cline { 2 - 3 } Osmotic dehydration process & OD & \\
\cline { 2 - 3 } & Before OD & After OD \\
\hline Ultrasound treatment for $10 \mathrm{~min}$ & US 10 & US 10 OD \\
Ultrasound treatment for 20 min & US 20 & US 20 OD \\
Ultrasound treatment for 30 min & US 30 & US 30 OD \\
Dipping for 10 min & DIP 10 & DIP 10 OD \\
Dipping for 20 min & DIP 20 & DIP 20 OD \\
Dipping for 30 min & DIP 30 & DIP 30 OD \\
\hline
\end{tabular}


indium ( $\left.\mathrm{mp} 156.60{ }^{\circ} \mathrm{C}\right)$, and zinc $\left(\mathrm{mp} 419.47{ }^{\circ} \mathrm{C}\right)$; heat flow was calibrated using the heat of fusion of indium $(\Delta \mathrm{H}=28.71 \mathrm{~J} / \mathrm{g})$. For the calibration, the same heating rate, as used for sample measurements, was applied under a dry nitrogen gas flux of $20 \mathrm{ml} \mathrm{min}^{-1}$. The samples were firstly cooled to $-60^{\circ} \mathrm{C}$, isothermally hold for $5 \mathrm{~min}$ at $-60{ }^{\circ} \mathrm{C}$ and then heated at $5{ }^{\circ} \mathrm{C} / \mathrm{min}$ to $110^{\circ} \mathrm{C}$.

The amount of freezable water $\left(\mathrm{g} / \mathrm{g}_{\mathrm{fw}}\right)$ was determined using the following equation (Quinn, Kampff, Smyth, \& McBrierty, 1988):

$x_{w}^{F}=\frac{\Delta \mathrm{H}}{\Delta \mathrm{H}_{\text {ice }}}$

where $\Delta \mathrm{H}\left(\mathrm{g} / \mathrm{g}_{\mathrm{fw}}\right)$ is the measured latent heat of melting of water for gram of sample obtained by the integration of the melting endothermic peak; $\Delta \mathrm{H}_{\text {ice }}(334 \mathrm{~J} / \mathrm{g})$ is the latent heat of melting of pure water at $0{ }^{\circ} \mathrm{C}$.

\subsection{Texture properties}

Texture properties were evaluated by performing a penetration test on outer pericarp kiwifruit tissue using a TA-HDi500 texture analyzer (Stable Micro Systems, Surrey, UK) equipped with a $5 \mathrm{~N}$ load cell. Experiment was run with a stainless steel probe of $6 \mathrm{~mm}$ diameter, with a rate and depth of penetration of $1 \mathrm{~mm} / \mathrm{s}$ and $6 \mathrm{~mm}$, respectively. The mean of fifteen replicates of kiwifruit slices was averaged for each ultrasound treatment and osmotic dehydration condition. The results were expressed as a maximum force (firmness, $\mathrm{N}$ ) necessary to penetrate the kiwifruit slices.

\subsection{Color}

The color changes of fresh, ultrasound treated and osmodehydrated samples were investigated using a spectro-photocolorimeter mod. Colorflex (Hunterlab, USA). The measurements were made using CIE $L^{*} a^{*} b^{*}$ scale. The instrument was calibrated with black and white tiles $\left(L^{*}=93.47, a^{*}=0.83, b^{*}=1.33\right)$ before the measurements. Results were expressed as $L^{*}$ (luminosity), hue angle $\left(\mathrm{h}^{\circ}\right)$ and total color difference $(\Delta \mathrm{E})$. The last two color parameters was calculated using Eqs. (3) and (4) respectively:

$\mathrm{h}^{\circ}=\tan ^{-1} \frac{b^{*}}{a^{*}}$

where: $a^{*}$ (red-green) and $b^{*}$ (yellow-blue) are parameters of color measurement (Vega-Gálvez et al., 2012).

$\Delta \mathrm{E}=\sqrt{(\Delta L *)^{2}+(\Delta a *)^{2}+(\Delta b *)^{2}}$

where: $\Delta L^{*}, \Delta a^{*}, \Delta b^{*}$ are differences of lightness, $a^{*}$ and $b^{*}$ parameter values of treated and untreated sample (Fijałkowska, Nowacka, Wiktor, Śledź, \& Witrowa-Rajchert, 2016).

The analyses were conducted in ten repetitions for randomly selected kiwifruit slices for each ultrasound treatment and osmotic dehydration condition.

\subsection{Chlorophyll content}

Chlorophyll a and b content was determined using a spectrophotometric method (AOAC, 1984) measuring the absorbance at 663 and $664 \mathrm{~nm}$ (Lichtenthaler \& Wellburn, 1983). Briefly, $250 \mathrm{mg}$ of freezedried untreated and treated kiwifruit samples were weighed into a centrifuge tubes and then a $5 \mathrm{ml}$ of $80 \%(\mathrm{v} / \mathrm{v})$ acetone solution was added. The mixture was blended and left in the dark for $15 \mathrm{~min}$.

The samples were centrifuged for $10 \mathrm{~min}$ at $10^{\circ} \mathrm{C}$ and $4500 \mathrm{rpm}$. The filtrate was added into a $5 \mathrm{ml}$ volumetric flask and made up to the volume by the $80 \%(\mathrm{v} / \mathrm{v})$ acetone. The absorbance at 663 (A663) and $645 \mathrm{~nm}$ (A645) were measured using a 752 model UV-visible spectrophotometer (Precise Scientific Instrument Co., Ltd. Shanghai, China). The concentrations were calculated by the following equations (Lichtenthaler \& Wellburn, 1983):

$$
\begin{aligned}
& C_{a}=12.21\left(A_{663}\right)-2.81\left(A_{646}\right) \\
& C_{b}=20.13\left(A_{646}\right)-5.03\left(A_{663}\right) \\
& C_{x+c}=\left(1000 A_{470}-3.27 C_{a}-104 C_{b}\right) / 229
\end{aligned}
$$

where: $C_{a}$ and $C_{b}$ are the concentrations $(\mathrm{mg} / \mathrm{l})$ of chlorophyll $a$ and $b$, respectively.

The analysis were conducted in triplicate.

\subsection{Statistical analysis}

Significance of the ultrasound treatment and osmotic dehydration effects was evaluated by means of one-way analysis of variance (ANOVA, 95\% significance level) using the software STATISTICA 6.0 (Statsoft Inc., Tulsa, UK).

\section{Results and discussion}

\subsection{Water activity and freezable water content}

Table 2 shows the water activity data for osmodehydrated kiwifruit samples with and without pretreatments. As it can be observed from the table, the application of both dipping or ultrasound treatment alone promoted a slight increase of $\mathrm{a}_{\mathrm{w}}$ values in comparison to the fresh kiwifruit sample $(0.983 \pm 0.004)$. Along the OD process the progressive decrease of water activity was observed. The lowest $\mathrm{a}_{\mathrm{w}}$ value $(0.970 \pm$ 0.003 ) was noticed in kiwifruit samples osmodehydrated for $120 \mathrm{~min}$ without any pretreatment, followed by samples treated with US for 20 and $30 \mathrm{~min}$ and OD for $120 \mathrm{~min}$, placing them in the same homogenous group from the statistic point of view $(p<0.05)$. Similar results were observed by other researchers. Water activity of Physalis (Luchese et al., 2015) and blueberries (Stojanovic \& Silva, 2007) samples was not affected by ultrasound application before osmotic dehydration. Generally, the preservation of plant tissues can be assured by water activity values lower than 0.6 (Maltini, Torreggiani, Venir, \& Bertolo, 2003). However also the reduction of water activity in our study, even though very slight, could probably help to reduce a possible growth of microorganism. In

\begin{tabular}{|c|c|c|c|c|c|c|c|}
\hline $\begin{array}{l}\text { OD time } \\
(\mathrm{min})\end{array}$ & OD & DIP 10 OD & DIP 20 OD & DIP 30 OD & US 10 OD & US 20 OD & US 30 OD \\
\hline 0 & $0.983 \pm 0.004^{\mathrm{b}}$ & $0.990 \pm 0.000^{\mathrm{a}}$ & $0.985 \pm 0.001^{\mathrm{ab}}$ & $0.987 \pm 0.004^{\mathrm{ab}}$ & $0.985 \pm 0.003^{\mathrm{ab}}$ & $0.988 \pm 0.003^{\mathrm{ab}}$ & $0.987 \pm 0.003^{\mathrm{ab}}$ \\
\hline 10 & $0.980 \pm 0.002^{\mathrm{bc}}$ & $0.985 \pm 0.003^{\mathrm{a}}$ & $0.981 \pm 0.005^{\mathrm{b}}$ & $0.977 \pm 0.002^{c}$ & $0.979 \pm 0.002^{\mathrm{bc}}$ & $0.982 \pm 0.001^{\mathrm{ab}}$ & $0.986 \pm 0.001^{\mathrm{a}}$ \\
\hline 20 & $0.978 \pm 0.003^{b c}$ & $0.979 \pm 0.002^{\mathrm{ab}}$ & $0.974 \pm 0.001^{\mathrm{d}}$ & $0.976 \pm 0.001^{\mathrm{cd}}$ & $0.977 \pm 0.002^{\mathrm{bcd}}$ & $0.982 \pm 0.001^{\mathrm{a}}$ & $0.978 \pm 0.004^{\mathrm{bcd}}$ \\
\hline 30 & $0.976 \pm 0.002^{\mathrm{bc}}$ & $0.982 \pm 0.001^{\mathrm{a}}$ & $0.976 \pm 0.003^{b c}$ & $0.974 \pm 0.003^{c}$ & $0.974 \pm 0.005^{c}$ & $0.980 \pm 0.000^{\mathrm{ab}}$ & $0.982 \pm 0.003^{\mathrm{a}}$ \\
\hline 60 & $0.976 \pm 0.002^{\mathrm{b}}$ & $0.981 \pm 0.001^{\mathrm{a}}$ & $0.974 \pm 0.001^{\mathrm{b}}$ & $0.975 \pm 0.002^{\mathrm{b}}$ & $0.975 \pm 0.001^{\mathrm{b}}$ & $0.979 \pm 0.002^{\mathrm{a}}$ & $0.979 \pm 0.001^{\mathrm{a}}$ \\
\hline 120 & $0.970 \pm 0.003^{\mathrm{d}}$ & $0.974 \pm 0.003^{\mathrm{abc}}$ & $0.977 \pm 0.001^{\mathrm{a}}$ & $0.973 \pm 0.003^{\mathrm{bcd}}$ & $0.975 \pm 0.001^{\mathrm{ab}}$ & $0.971 \pm 0.001^{\mathrm{cd}}$ & $0.972 \pm 0.003^{\mathrm{bcd}}$ \\
\hline
\end{tabular}

Table 2

Water activity $\left(\mathrm{a}_{\mathrm{w}}\right)$ of osmodehydrated samples as a function of different pretreatments and OD times.

Values in the same column followed by different letters differ significantly at $\mathrm{p}<0.05$ levels. 


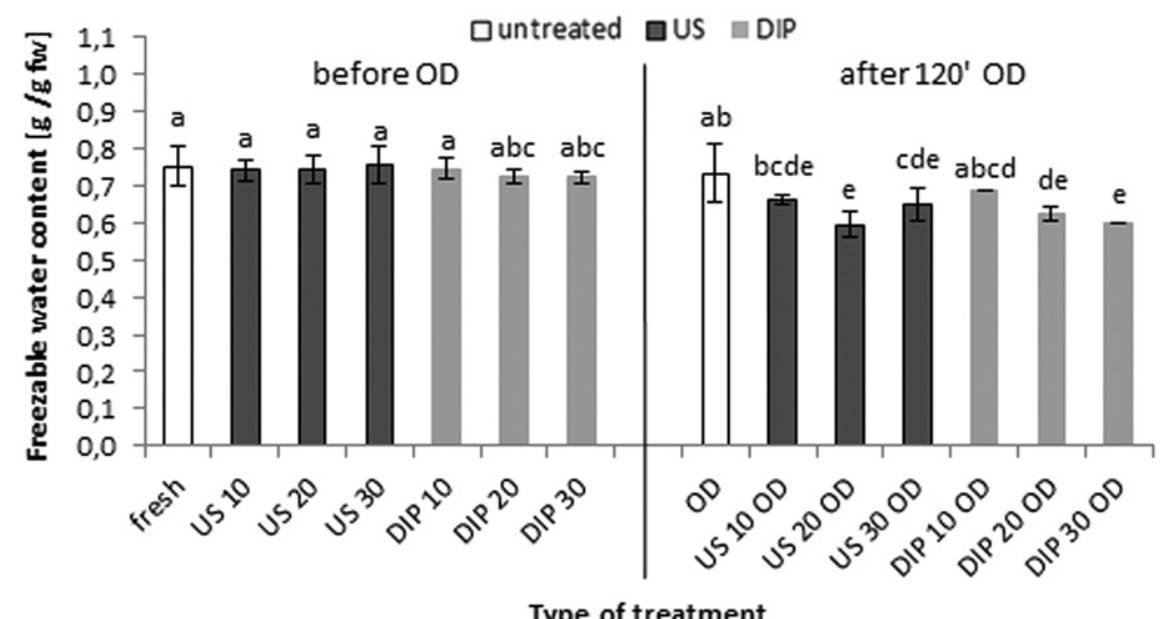

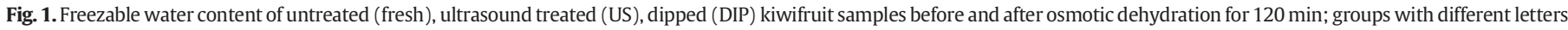
differ significantly $(\mathrm{p}<0.05)$.

fact, Gianotti et al. (2001) observed a decrease of microbial growth in kiwifruit samples, which were dehydrated in $65^{\circ}$ Brix sucrose solution even if the final $\mathrm{a}_{\mathrm{w}}$ values were in range of $0.99-0.98$. This probably because the sucrose uptake promoted an increase of viscosity of kiwifruit liquid phase, affecting the kinetic rate of microbial growth. Moreover, Birmpa, Sfika, and Vantarakis (2013) has proven that US treatment reduce the number of selected bacteria. However, to ensure the stability of the products it is necessary to subject OD product to a drying process, that prevents loss of food quality caused by microbial activity (Maltini et al., 2003).

Another parameter related to the stability of fruit products is the freezable water content. Fresh, non-treated samples presented the highest freezable water content, which was comparable with the samples subjected to OD process for 120 min without any pretreatment (Fig. 1). Tylewicz et al. (2011) reported that the freezable water content could be influenced by the kiwifruit variety, in fact in their study the significant differences in freezable water content were presented only when Actinidia chinensis was used for the experiment rather that $A$. deliciosa. The authors observed that using $A$. deliciosa an increase of the temperature process (from 25 to $35^{\circ} \mathrm{C}$ ) was necessary to reduce freezable water content.
The US application of each treatment time has a similar effect on freezable water content of kiwifruit as OD process for 120 min without any pretreatment. When combined treatments have been used, the freezable water content was significantly reduced in dehydrated samples pretreated with US for $20 \mathrm{~min}$ and these dipped in distilled water for $30 \mathrm{~min}$.

\subsection{Analysis of texture properties}

The penetration test is one of the most acceptable methods for measuring the firmness of fruit and vegetables (Camarena, Martínez-Mora, \& Ardid, 2007). The results of above mentioned test carried out on fresh (untreated) and osmodehydrated kiwifruit samples with and without pretreatments are presented in Fig. 2, proving that the type of treatment and its duration affect the maximum penetration force.

The firmness of US treated samples was lower in comparison to the untreated one, which were characterized by the values equal to $16 \pm$ $2 \mathrm{~N}$. However, in general, the effect of US treatment time on plant tissue is not clearly stated. In the present investigation, the observed changes in firmness after 10, 20 and 30 min of US application were statistically significant in comparison to untreated sample, showing the lowest

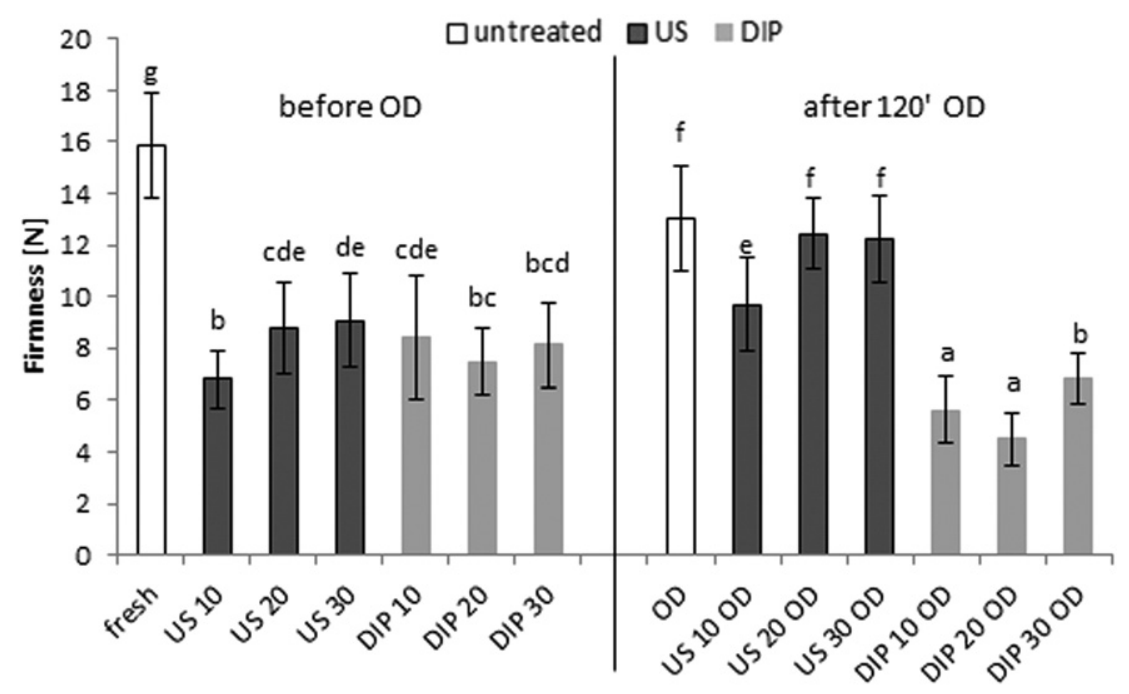

Type of treatment

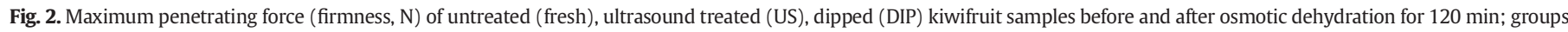
with different letters differ significantly $(p<0.05)$. 


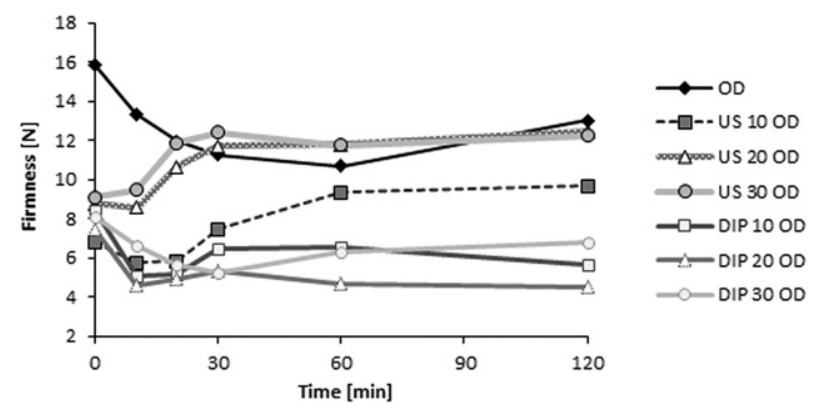

Fig. 3. Firmness changes of untreated (OD) and pretreated (US and DIP) kiwifruit slices subjected to OD as a function of immersion time.

values $(6.8 \pm 1.1 \mathrm{~N})$ in samples treated with US for $10 \mathrm{~min}$ (US 10). Other authors obtained similar results on ultrasound treated chickpeas (Yildirim, Öner, \& Bayram, 2013) and fish products (Gélvez Ordóñez \& Fuentes Berrio, 2011). Similarly, samples dipped in distilled water were characterized by a lower maximum penetration force in comparison to untreated kiwifruits. However, in this case the time of dipping did not significantly influence the maximum force needed to penetrate the slices of kiwifruit.

Osmotic dehydration of untreated kiwifruits (OD) slices caused a reduction of $18 \%$ of the maximum force required to penetrate the samples in comparison to the fresh sample. Maximum forces of all US pretreated and subsequently osmodehydrated kiwifruit samples were $22-39 \%$ lower in comparison to the OD sample. The decrease of texture parameters could be related to loss of turgor pressure, caused by the protoplast shrinkage and its detachment from the cell wall, that was also observed by Nieto, Vicente, Hodara, Castro, and Alzamora (2013) in apple dehydrated to the same $\mathrm{a}_{\mathrm{w}}$ level as in the present study (0.97).

Sample treated for 10 min of US and then osmodehydrated for 120 min (US 10 OD) showed significantly lower value of maximum penetration force in comparison to longer time ultrasound treatment (20 and $30 \mathrm{~min}$ - US 20 OD, US 30 OD) before osmotic dehydration (Fig. 2 ). Texture is determined by the microstructure of the product (Cao et al., 2010; Lee \& Feng, 2011, chap. 22) and the changes in maximum penetration force might be related to the alteration of sample microstructure, caused by ultrasound waves (Fernandes et al., 2008; Nowacka \& Wedzik, 2016). Cao et al. (2010) showed that the application of ultrasound at $40 \mathrm{kHz}$ has maintained strawberries firmness during 8-days refrigerated storage, that was connected with structural changes.
Dipped and subsequently osmodehydrated samples (DIP OD) were characterized by the lowest force, which could be due to the changes caused by water penetration in the samples and leaching of water soluble substances into the surroundings. Similar trend was observed for work parameter, which was done to penetrate kiwifruit slices (data not shown).

The firmness kinetics of US and DIP pretreated kiwifruit samples subjected to different times of OD treatment are shown in Fig. 3. The untreated kiwifruit sample (OD) underwent a decrease of firmness values during the first hour of osmotic dehydration process. After $120 \mathrm{~min}$ an increase of the firmness parameter occurred, which was associated with greater loss of water during the osmotic dehydration (see Nowacka et al., 2014). Ultrasound waves applied before OD treatment to kiwifruit slices caused a notable reduction of their firmness. US pretreatment for 10 min caused the highest changes of osmodehydrated samples firmness in comparison to the untreated ones. During the OD process US treated samples exhibited an increase of firmness and at the end of the process obtained values were similar (US 20 OD and US 30 OD) or lower (US 10 OD) in comparison to untreated samples. However, kiwifruit dipped in distilled water and subjected to OD treatment had the lowest firmness values among all the samples.

\subsection{Color and chlorophyll changes}

The color of foods is one of the most important characteristics, which determines quality of both raw materials and processed food products, affecting their acceptability by the consumers (Pingret, Fabiano-Tixier, \& Chemat, 2013).

Fresh kiwifruit samples were characterized by $L^{*}$ parameter value equal to $42.4 \pm 3.4$; US pretreated kiwifruit samples presented an alteration of their color, reflected by higher values of $L^{*}$ parameter (Fig. 4), which could be connected to US treatment in liquid medium. When the plant tissue is immersed in the medium during the US treatment, the color is better preserved due to the limited access of air (Wiktor, Sledz, Nowacka, Rybak, \& Witrowa-Rajchert, 2016). However different results were obtained by Luchese et al. (2015) for ultrasound treated Physalis tissue subjected to OD, where its color, as well as carotenoid content, have not be affected by US treatment. However, during ultrasound processing of grapefruit juice (Aadil et al., 2013) and apple tissue (Wiktor et al., 2016) a decrease of the $L^{*}$ parameter with increasing treatment time was noticed. These changes could be connected to cavitation phenomenon, which occurs during ultrasound application. Moreover, free radicals and sonochemicals may be produced during

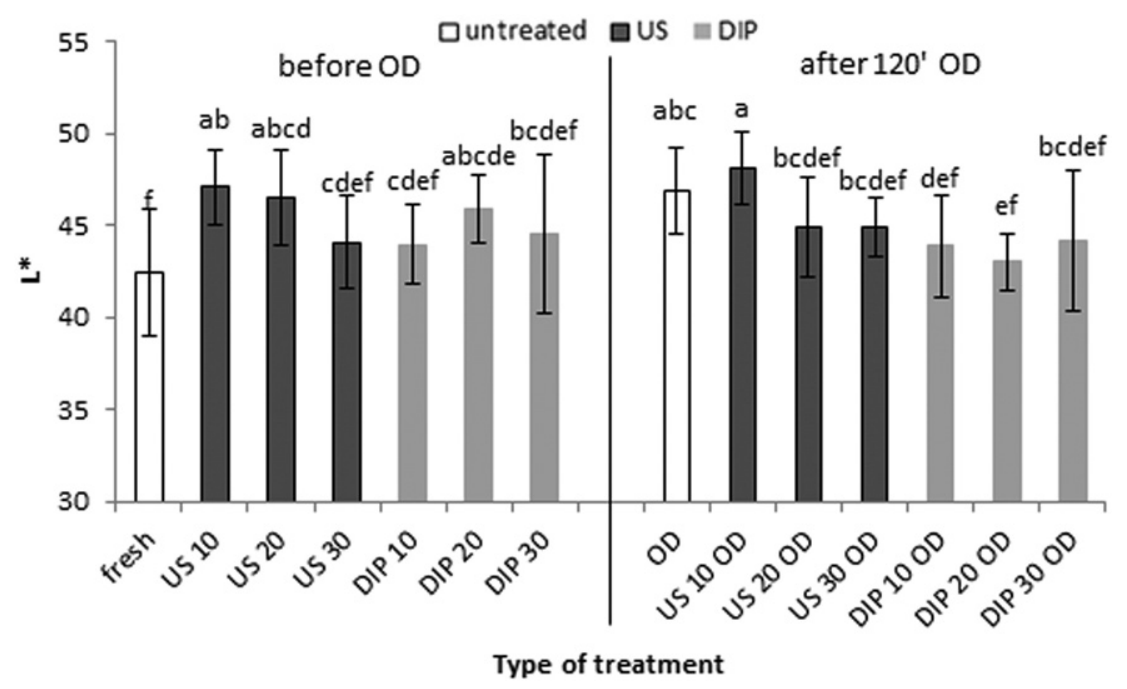

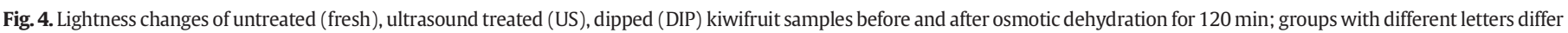
significantly $(\mathrm{p}<0.05)$. 


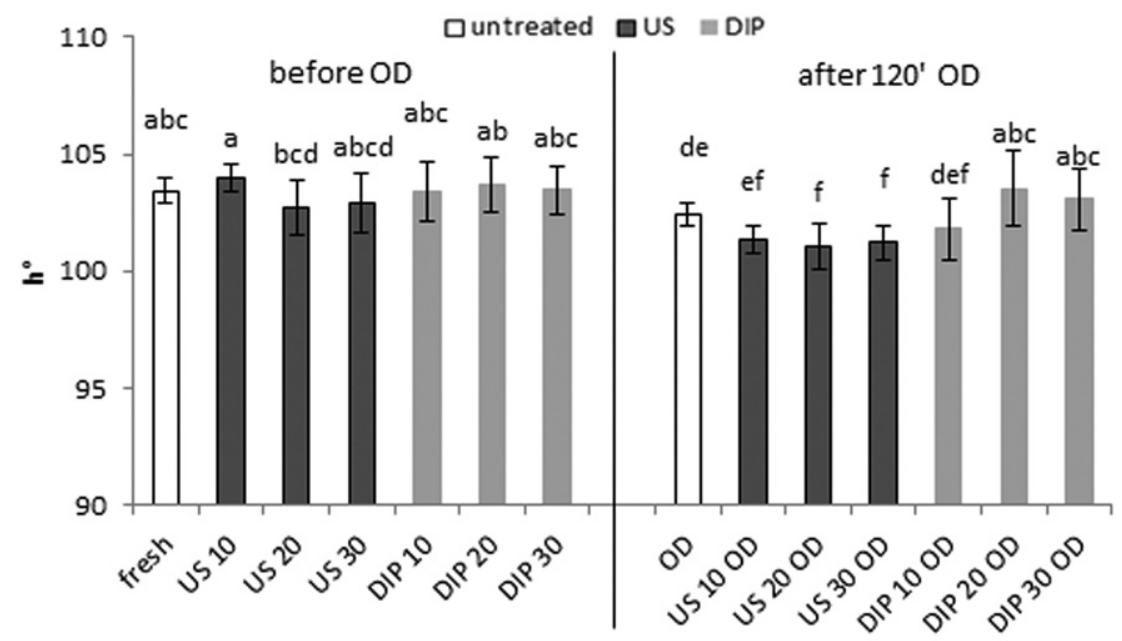

Type of treatment

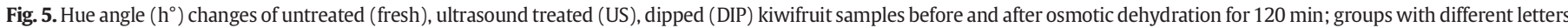
differ significantly $(\mathrm{p}<0.05)$.

US treatment (Bermudez-Aguirre, Mobbs, \& Barbosa-Canovas, 2011), having an influence on different food properties, such as color.

After 120 min of OD treatment an increase of lightness was observed for the untreated sample. This is probably due to the mass transfer phenomena, including either the leaching of compounds responsible for the color, such as chlorophylls, to the osmotic solution (Rząca, WitrowaRajchert, Tylewicz, \& Dalla Rosa, 2009). However, when US and DIP were applied as pretreatments before OD no statistically significant changes in $\mathrm{L}^{*}$ parameter in comparison to the OD sample were noticed.

The observed changes in terms of hue angle $\left(\mathrm{h}^{\circ}\right)$ color parameter (Fig. 5) were less pronounced between the samples. After US or DIP pretreatment the values of $h^{\circ}$ were unchanged in comparison to the untreated kiwifruit. Similar results were observed by Wiktor et al. (2016) for US treated apple tissue. The US pretreatment followed by OD promoted a decrease of $h^{\circ}$ parameter, which resulted significant for 20 and 30 min US treated kiwifruits, indicating a hue color change for these samples from green to light green.

The $L^{*}, a^{*}$ and $b^{*}$ color parameters were used to calculate the total color difference $(\Delta E)$, which described the overall changes in reference to color of untreated samples. US treated kiwifruits were characterized by $\Delta \mathrm{E}$ in the range from 1.76 to 5.12 . According to the interpretation given by Choi, Kim, and Lee (2002) the $\Delta \mathrm{E}$ value higher than 2 confirms the visible difference. Fig. 6 shows that the shorter US treatment time (10 and $20 \mathrm{~min}$ ) caused noticeable changes of $\Delta \mathrm{E}$ value in comparison to untreated sample, while the 30 min US treatment did not influence the color of kiwifruit. The results are not in agreement with those presented in literature, in fact Birmpa et al. (2013) observed a higher color changes in lettuce and strawberries followed by longer US treatment times.

High values of $\Delta \mathrm{E}$ were observed in $120 \mathrm{~min}$ OD treated samples. However, US treated samples and the osmodehydrated resulted in better color retention compared to the untreated ones, with one exception (US 10 OD).

The color of plant tissue is linked to the presence of natural pigments (Maskan, 2001). In the kiwifruits, chlorophylls are the major group of color compounds, which gives to the fruit a typical green color (Lawes, 1989). The content of chlorophyll in the fresh kiwifruit sample was $85.4 \pm 3.2 \mathrm{mg} / \mathrm{kg} \mathrm{s.s.} \mathrm{(Fig.} \mathrm{7).} \mathrm{The} \mathrm{changes} \mathrm{in} \mathrm{chlorophyll} \mathrm{content} \mathrm{of}$ kiwifruit seemed to depend on the time of US application, showing the highest value when 20 min of US was applied. This effect may be the

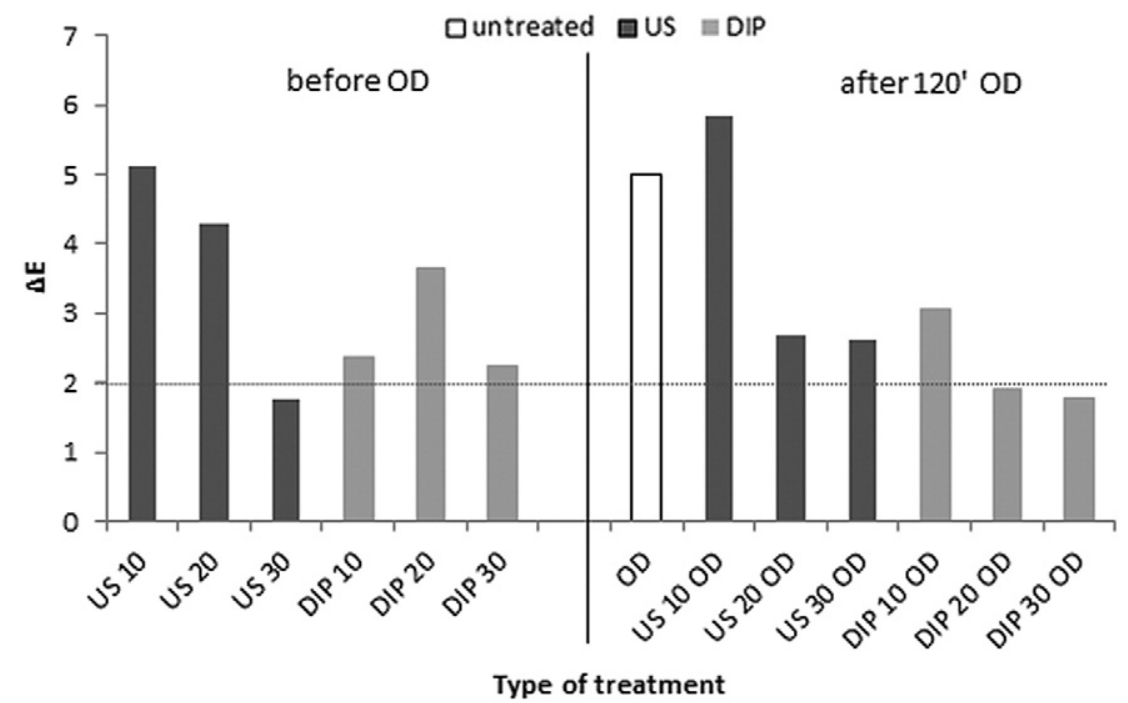

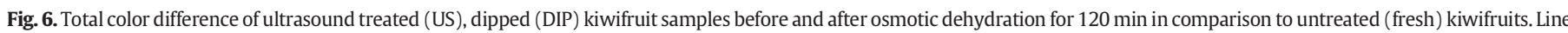
on $\Delta \mathrm{E}=2$ indicates a significant color change. 


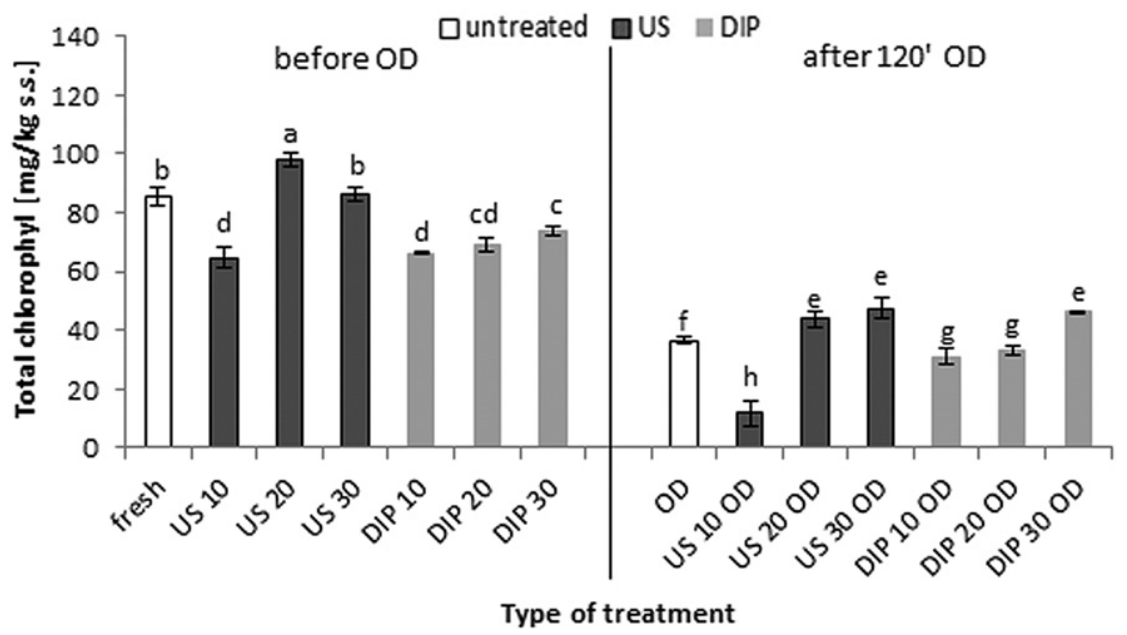

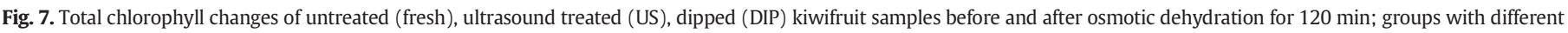
letters differ significantly $(\mathrm{p}<0.05)$.

results of several phenomena such as better extraction of bioactive compounds in US treated tissue (Tao, Wu, Zhang, \& Sun, 2014; Witrowa-Rajchert, Wiktor, Sledz, \& Nowacka, 2014; Wiktor et al., 2016) and leakage of these substances into the surrounding medium (Rząca et al., 2009). Moreover, during US treatment the reactive forms of oxygen (ROS) are created as an effect of cavitation phenomena, causing the degradation of bioactive compounds (Fonteles et al., 2012; Wiktor et al., 2016). This effect may influence the lower amount of total chlorophyll content when 30 min of US treatment was applied. The degradation of bioactive compounds after application of US for long times was also noted for polyphenols content (Wiktor et al., 2016), $\beta$-carotene (Nowacka \& Wedzik, 2016) and antioxidant properties (Fonteles et al., 2012). Furthermore, the enzymatic and/or nonenzymatic reactions can cause brown pigmented substances, leading to breakdown of coloring pigments and chlorophyll degradation (Leunda, Guerrero, \& Alzamora, 2000; Maskan, 2001; Aadil et al., 2013).

OD without any pretreatment resulted in chlorophyll degradation of $57 \%$ in comparison to fresh, untreated sample. However, US treatment conducted for 20 and 30 min (US 20 OD, US 30 OD) contributed to increase the content of this biological component. Similar results were obtained by Sledz, Wiktor, Rybak, and Witrowa-Rajchert (2014) for chlorophyll content in parsley leaves. Application of ultrasound for longer time may favour a better extraction of bioactive compounds (Rawson, Tiwari, Tuohy, O'Donnell, \& Brunton, 2011; Nowacka \& Wedzik, 2016). However, similar total chlorophyll content was found in the DIP 30 OD kiwifruit sample.

\section{Conclusion}

The obtained results show that the effect of ultrasound on overall kiwifruit quality parameters was not clearly stated, in particular referring to treatment time. Ultrasound pretreatment alone, when applied for certain times (especially for $20 \mathrm{~min}$ ), positively affected the chlorophyll content. Texture was the only quality parameter that was negatively influenced by all the tested ultrasound conditions. However, when combined with osmotic dehydration treatment ultrasound, at selected times, was able to maintain and sometimes improve the kiwifruit characteristics in comparison to the osmotic dehydration alone treated sample. Further studies are necessary to select the best ultrasound process conditions in order to improve both the mass transfer during osmotic dehydration process as well as the quality and stability of the treated products.

\section{Acknowledgments}

Urszula Tylewicz would like to acknowledge Emilia-Romagna Region (POR-FESR 2007-2013) for financial support. Authors would like to acknowledge Sara Gabaldo for her help.

\section{References}

Aadil, R. M., Zeng, X. A., Han, Z., \& Sun, D. W. (2013). Effects of ultrasound treatments on quality of grapefruit juice. Food Chemistry, 141, 3201-3206.

Alzamora, S. M., Castro, M. A., Vidales, S. I., Nieto, A. B., \& Salvatori, D. (2000). The role of tissue microstructure in the textural characteristics of minimally processed fruits. In S. M. Alzamora, M. S. Tapia, \& A. Lopez-Malo (Eds.), In minimally processed fruits and vegetables fundamental aspects and applications (pp. 153-172). Maryland: Aspen Publishers Inc.

AOAC (1984). Official methods of analysis of the Association of Official Analytical Chemists (14th ed.). Washington, DC: Association of Official Analytical Chemists.

Benedito, J., Ortuño, C., Castillo-Zamudio, R. I., \& Mulet, A. (2015). Microbial inactivation by ultrasound assisted supercritical fluids. Physics Procedia, 70, 824-827.

Bermudez-Aguirre, D., Mobbs, T., \& Barbosa-Canovas, G. V. (2011). Ultrasound applications in food processing. In H. Feng, G. V. Barbosa-Canovas, \& Weiss (Eds.), Ultrasound technologies for food and bioprocessing food engineering series (pp. 65-105). New York: Springer.

Birmpa, A., Sfika, V., \& Vantarakis, A. (2013). Ultraviolet light and ultrasound as non-thermal treatments for the inactivation of microorganisms in fresh ready-to-eat foods. International Journal of Food Microbiology, 167, 96-102.

Camarena, F., Martínez-Mora, J. A., \& Ardid, M. (2007). Ultrasonic study of the complete dehydration process of orange peel. Postharvest Biology and Technology, 43, 115-120.

Cao, S., Hu, Z., Pang, B., Wang, H., Xie, H., \& Wu, F. (2010). Effect of ultrasound treatment of fruit decay and quality maintenance in strawberry after harvest. Food Control, 21, 529-534.

Cárcel, J. A., Garcia Perez, J. V., Riera, E., \& Mulet, A. (2007). Influence of high-intensity ultrasound on drying kinetics of persimmon. Drying Technology, 25, 185-193.

Cheng, X. F., Zhang, M., Adhikari, B., \& Islam, M. N. (2014). Effect of power ultrasound and pulsed vacuum treatments on the dehydration kinetics, distribution, and status of water in osmotically dehydrated strawberry: A combined NMR and DSC study. Food and Bioprocess Technology, 7(10), 2782-2792.

Chiralt, A., Martinez-Navarrete, N., Martinez-Monzo, J., Talens, P., Moraga, G., Ayala, A., \& Fito, P. (2001). Changes in mechanical properties throughout osmotic processes. Cryoprotectant effect. Journal of Food Engineering, 49, 129-135.

Choi, M. H., Kim, G. H., \& Lee, H. S. (2002). Effects of ascorbic acid retention on juice color and pigment stability in blood orange (Citrus sinensis) juice during refrigerated storage. Food Research International, 35(8), 753-759.

Comandini, P., Blanda, G., Soto-Caballero, M. C., Sala, V., Tylewicz, U., Mujica-Paz, H., ... Gallina Toschi, T. (2013). Effects of power ultrasound on immersion freezing parameters of potatoes. Innovative Food Science E Emerging Technologies, 18, 120-125.

Cornillon, P. (2000). Characterization of osmotic dehydrated apple by NMR and DSC. LWT, 33, 261-267.

Dalla Rosa, M., \& Bressa, F. (1995). Problematiche, tecnologie e derivati della trasformazione industriale dell'actinidia (in Italian). Frutticoltura, 4.

El-Aouar, A. A., Azoubel, P. M., \& Xidieh Murr, F. E. (2003). Drying kinetics of fresh and osmotically pre-treated papaya. Journal of Food Engineering, 59(1), 85-91.

Feng, H., \& Yang, W. (2006). Power ultrasound. In Y. H. Hui (Ed.), Handbook of food science, technology and engineering. 3. (pp. 121). Boca Raton: Taylor \& Francis Group.

Fernandes, F. A. N., \& Rodrigues, S. (2007). Ultrasound as pre-treatment for drying of fruits: Dehydration of banana. Journal of Food Engineering, 82, 261-267. 
Fernandes, F. A. N., Gallão, M. I., \& Rodrigues, S. (2008). Effect of osmotic dehydration and ultrasound pre-treatment on cell structure: Melon dehydration. LWT, 41, 604-610.

Fernandes, F. A. N., Gallão, M. I., \& Rodrigues, S. (2009). Effect of osmosis and ultrasound on pineapple cell tissue structure during dehydration. Journal of Food Engineering, 90, 186-190.

Fijałkowska, A., Nowacka, M., Wiktor, A., Śledź, M., \& Witrowa-Rajchert, D. (2016). Ultrasound as a pre-treatment method to improve drying kinetics and sensory properties of dried apple. Journal of Food Process Engineering, 39(3), 256-265.

Fonteles, T. V., Costa, M. G. M., de Jesus, A. L. T., de Miranda, M. R. A., Fernandes, F. A. N., \& Rodrigues, S. (2012). Power ultrasound processing of cantaloupe melon juice: Effects on quality parameters. Food Research International, 48, 41-48.

Garcia, C. C., Mauro, M. A., \& Kimura, M. (2007). Kinetics of osmotic rehydration and airdrying of pumpkins (Cucurbita moschata). Journal of Food Engineering, 82, 284-291.

Gélvez Ordóñez, V. M., \& Fuentes Berrio, L. (2011). Effect of ultrasound and magnetic fields on $\mathrm{pH}$ and texture (TPA) in beef loin tuna (Thunnus albacares)Proceedings of 11 th ICEF, FMS900.

Gianotti, A., Sacchetti, G., Guerzoni, M. E., \& Dalla Rosa, M. (2001). Microbial aspects on short-time osmotic treatment of kiwifruit. Journal of Food Engineering, 49, 265-270.

Jambrak, A. R., Mason, T. J., Paniwnyk, L., \& Lelas, V. (2007). Accelerated drying of button mushrooms, Brussels sprouts and cauliflower by applying power ultrasound and its rehydration properties. Journal of Food Engineering, 81(1), 88-97.

Kek, S. P., Chin, N. L., \& Yusof, Y. A. (2013). Direct and indirect power ultrasound assisted pre-osmotic treatments in convective drying of guava slices. Food and Bioproducts Processing, 91(4), 495-506.

Kutyła-Olesiuk, A., Nowacka, M., Wesoły, M., \& Ciosek, P. (2013). Evaluation of organoleptic and texture properties of dried apples by hybrid electronic tongue. Sensors and Actuators B: Chemical, 187, 234-240.

Lawes, G. S. (1989). The effect of shading on the chlorophyll content of 'Hayward' kiwifruit. New Zealand Journal of Crop and Horticultural Science, 17(3), 245-249.

Lee, H., \& Feng, H. (2011). Effect of power ultrasound on food quality. In H. Feng, G. V. Barbosa-Cánovas, \& J. Weiss (Eds.), Ultrasound technologies for food and bioprocessing (pp. 559-582). Springer Science + Business Media, LLC.

Leunda, M. A., Guerrero, S. N., \& Alzamora, S. M. (2000). Color and chlorophyll content changes of minimally processed kiwifruit. Journal of Food Processing and Preservation, 24(1), 17-38.

Lichtenthaler, H. K., \& Wellburn, A. R. (1983). Determinations of total carotenoids and chlorophylls $a$ and $b$ of leaf extracts in different solvents. Biochemical Society Transactions, 11, 591-592.

Luchese, C. L., Gurak, P. D., \& Ferreira Marczak, L. D. (2015). Short communication: Osmotic dehydration of Physalis - Influence of ultrasound pretreatment. Food Engineering Reviews, 7, 193-197. http://dx.doi.org/10.1007/s12393-014-9086-7.

Maltini, E., Torreggiani, D., Venir, E., \& Bertolo, G. (2003). Water activity and the preservation of plant foods. Food Chemistry, 82, 79-86.

Maskan, M. (2001). Kinetics of colour change of kiwifruits during hot air and microwave drying. Journal of Food Engineering, 48, 169-175.

Mason, T. J. (1998). Power ultrasound in food processing - The way forward. In M. J. W. Povey, \& T. J. Mason (Eds.), Ultrasound in food processing (pp. 105-126). London: Blackie Academic and Professional.

McClements, D. J. (1995). Advances in application of ultrasound in food analysis and processing. Trends in Food Science and Technology, 6, 293-299.

Nieto, A. B., Vicente, S., Hodara, K., Castro, M. A., \& Alzamora, S. M. (2013). Osmotic dehydration of apple: Influence of sugar and water activity on tissue structure, rheological properties and water mobility. Journal of Food Engineering, 119, 104-114.

Nowacka, M., \& Wedzik, M. (2016). Effect of ultrasound treatment on microstructure, colour and carotenoid content in carrot tissue. Applied Acoustics, 103, 163-171.

Nowacka, M., Wiktor, A., Sledz, M., Jurek, N., \& Witrowa-Rajchert, D. (2012). Drying of ultrasound pretreated apple and its selected physical properties. Journal of Food Engineering, 113(3), 427-433.

Nowacka, M., Tylewicz, U., Laghi, L., Dalla Rosa, M., \& Witrowa-Rajchert, D. (2014). Effect of ultrasound on the water state in kiwifruit during osmotic dehydration. Food Chemistry, 144, 18-25.

Nuncio-Jáuregui, N., Calín-Sánchez, A., Carbonell-Barrachina, A., \& Hernández, F. (2014). Changes in quality parameters, proline, antioxidant activity and color of pomegranate (Punica granatum L.) as affected by fruit position within tree, cultivar and ripening stage. Scientia Horticulturae, 165, 181-189.

Osorio, C., Franco, M. S., Castaño, M. P., González-Miret, M. L., Heredi, F. J., \& Morales, A. L. (2007). Colour and flavour changes during osmotic dehydration of fruits. Innovative Food Science \&' Emerging Technologies, 8(3), 353-359.
Panarese, V., Tylewicz, U., Santagapita, P., Rocculi, P., \& Dalla Rosa, M. (2012a). Isothermal and differential scanning calorimetreies to evaluate structural and metabolic alteration of osmo-dehydrated kiwifruit as a function of ripening stage. Innovative Food Science \& Emerging Technologies, 15, 66-71.

Panarese, V., Laghi, L., Pisi, A., Tylewicz, U., Dalla Rosa, M., \& Rocculi, P. (2012b). Effect of osmotic dehydration on Actinidia deliciosa kiwifruit: A combined NMR and ultrastructural study. Food Chemistry, 132(4), 1706-1712.

Pathare, P. B., Opara, U. L., \& Al-Julanda Al-Said, F. (2013). Colour measurement and analysis in fresh and processed foods: A review. Food and Bioprocess Technology, 6, 36-60.

Perera, C. O. (2005). Selected quality attributes of dried foods. Drying Technology, 23(4), $717-730$.

Pingret, D., Fabiano-Tixier, A. -S., \& Chemat, F. (2013). Degradation during application of ultrasound in food processing: A review. Food Control, 31(2), 593-606.

Quinn, F. X., Kampff, E., Smyth, G., \& McBrierty, V. J. (1988). Water in hydrogels 1. A study of water in poly( $N$-vinyl-2-pyrrolidone/methylmethacrylate) copolymer. Macromolecules, 21, 3191-3198.

Raso, J., Manas, P., Pagan, R., \& Sala, F. J. (1999). Influence of different factors on the output power transferred into medium by ultrasound. Ultrasonics Sonochemistry, 5, 157-162.

Rawson, A., Tiwari, B. K., Tuohy, M. G., O'Donnell, C. P., \& Brunton, N. (2011). Effect of ultrasound and blanching pretreatments on polyacetylene and carotenoid content of hot air and freeze dried carrot discs. Ultrasonics Sonochemistry, 18(5), 1172-1179.

Rudy, S, Dziki, D. Krzykowski, A Polak, R. Biernacka, B, \& Kulig, R. (2013). Influence of osmotic dehydration on convective drying process of cherries. TEKA. Commission of Motorization and Energetics in Agriculture, 13(1), 145-148.

Rząca, M., Witrowa-Rajchert, D., Tylewicz, U., \& Dalla Rosa, M. (2009). Mass exchange in osmotic dehydration process of kiwi fruits. Food. Science. Technology. Quality, 6(67), 140-149.

Schössler, K., Thomas, T., \& Knorr, D. (2012). Modification of cell structure and mass transfer in potato tissue by contact ultrasound. Food Research International, 49(1), 425-431.

Silva, K. S., Fernandes, M. A., \& Mauro, M. A. (2014). Effect of calcium on the osmotic dehydration kinetics and quality of pineapple. Journal of Food Engineering, 134, 37-44.

Simal, S., Benedito, J., Sanchez, E. S., \& Rossello, C. (1998). Use of ultrasound to increase mass transport rates during osmotic dehydration. Journal of Food Engineering, 36(3) 323-336.

Sledz, M., Wiktor, A., Rybak, K., \& Witrowa-Rajchert, D. (2014). Quality changes during microwave-convective drying of ultrasound and water steam blanching pretreated parsley leaves (pp. 6)Proceedings of 19th international drying symposium, 24-27.08.2014. Lyon, France: EDP Sciences (2014c. ISBN 978-2-7598-1631-6).

Stojanovic, J., \& Silva, J. L. (2007). Influence of osmotic concentration, continuous high frequency ultrasound and dehydration on antioxidants, colour and chemical properties of rabbiteye blueberries. Food Chemistry, 101, 898-906.

Tao, Y., Wu, D., Zhang, Q. A., \& Sun, D. W. (2014). Ultrasound-assisted extraction of phenolics from wine lees: Modeling, optimization and stability of extracts during storage. Ultrasonics Sonochemistry, 21(2), 706-715.

Tarleton, E. S., \& Wakeman, R. J. (1998). Ultrasonically assisted separation process. In M. J. W. Povey, \& T. J. Mason (Eds.), Ultrasound in food processing (pp. 193-218). Glasgow, U.K.: Blackie Academic and Professional.

Tylewicz, U., Rząca, M., Rocculi, P., Romani, S., \& Dalla Rosa, M. (2010). Comparison of quality characteristics evaluation during osmotic dehydration of Hayward and Hort16A kiwifruit. Fruit Processing, 4(2010), 150-153.

Tylewicz, U., Panarese, V., Laghi, L., Rocculi, P., Nowacka, M., Placucci, G., \& Dalla Rosa, M. (2011). NMR and DSC water study during osmotic dehydration of Actinidia deliciosa and Actinidia chinensis kiwifruit. Food Biophysics, 6(2), 327-333.

Vega-Gálvez, A., Ah-Hen, K., Chacana, M., Vergana, J., Martínez-Monzó, J., García-Segovia P., ... Di Scala, K. (2012). Effect of temperature and air velocity on drying kinetics, antioxidant capacity, total phenolic content, colour, texture and microstructure of apple (var. Granny Smith) slices. Food Chemistry, 132(1), 51-59.

Wiktor, A., Sledz, M., Nowacka, M., Rybak, K., \& Witrowa-Rajchert, D. (2016). The influence of immersion and contact ultrasound treatment on selected properties of the apple tissue. Applied Acoustics, 103, 136-142.

Witrowa-Rajchert, D., Wiktor, A., Sledz, M., \& Nowacka, M. (2014). Selected emerging technologies to enhance drying process. A review. Drying Technology, 32, 1386-1396.

Yildirim, A., Öner, M. D., \& Bayram, M. (2013). Effect of soaking and ultrasound treatments on texture of chickpea. Journal of Food Science and Technology, 50(3), 455-465. 